\title{
THE ROLE OF BANK RESTRUCTURING IN RECOVERING FROM CRISES: MEXICO 1995-98
}

\author{
Anne Krueger \\ Aaron Tornell \\ Working Paper 7042 \\ http://www.nber.org/papers/w7042
NATIONAL BUREAU OF ECONOMIC RESEARCH 1050 Massachusetts Avenue
Cambridge, MA 02138
March 1999

The views expressed in this paper are those of the authors and do not reflect those of the National Bureau of Economic Research.

C 1999 by Anne Krueger and Aaron Tornell. All rights reserved. Short sections of text, not to exceed two paragraphs, may be quoted without explicit permission provided that full credit, including ${ }^{\odot}$ notice, is given to the source. 
The Role of Bank Restructuring in Recovering

from Crises: Mexico 1995-98

Anne Krueger and Aaron Tornell

NBER Working Paper No. 7042

March 1999

\begin{abstract}
In this paper we analyze the evolution of the Mexican economy between 1995 and 1998. The remarkable quick recovery seen in aggregate activity has not been uniform across the economy. The tradable sector has grown strongly, while the non-tradable sector has recuperated only sluggishly. This asymmetric response is intimately linked with the severe credit crunch that Mexico has experienced since 1995. Although fresh domestic bank lending dried up, tradable firms obtained financing in the international capital market. This was not the case in the non-tradable sector. A phenomenon that has gone hand in hand with the credit crunch is the steady increase in the share of non-performing loans. We analyze the reasons for this increase, the rationale for the partial bailout policy adopted in 1995, and we investigate why this policy stance did not solve the banking problem. An important lesson is that non-performing loans are unlikely to disappear on their own, even under a high GDP growth scenario. Furthermore, the existence of non-performing loans presents an obstacle for the banking system to adequately perform its functions. This raises the question of whether an alternative strategy under which all non-performing loans were recognized at once and the fiscal costs were all paid up-front would have been preferable.
\end{abstract}

Anne Krueger

Department of Economics

Stanford University

579 Serra Mall

Landau Economics Building, Rm. 153

Stanford, CA 94305-6072

and NBER

akrueger@leland.stanford.edu
Aaron Tornell

Department of Economics

Harvard University

Cambridge, MA 02138

and NBER

aaron_tornell@harvard.edu 


\section{INTRODUCTION}

As is well known, Mexico experienced a serious economic crisis in the early 1980s, when the country's officials were forced to announce that Mexico could no longer voluntarily service her debt. For the world, that was the beginning of the "debt crisis", coming as a huge surprise in light of Mexico's status as an oil exporter. For Mexico, that was the beginning of a period of major economic difficulties.

Until 1985, the Mexican authorities attempted to use traditional restrictive macroeconomic policies and government controls to stabilize the economy, nationalizing the banks, tightening quantitative restrictions on imports, and reducing the fiscal deficit. By the mid-1980s, however, it was evident that earlier Mexican policies - of heavy intervention and controls - had failed and that far-reaching fundamental economic reform would be necessary if prospects for sustained economic growth were to improve. Indeed, after three years of deteriorating conditions from 1982 to 1985 , the reforms were viewed as essential even for short run "survival".

Thereafter, Mexico underwent a series of far-reaching reforms. Although growth rates were never really high, the economy did progress, inflation slowed markedly, fiscal stability was achieved, imports were liberalized, major privatizations were accomplished, and by the 
1990s, many pointed to Mexico as a splendid example of successful economic policy reform. Mexico had even negotiated the North American Free Trade Agreement with Canada and the United States, thus contemplating a highly open economy in future years.

In December 1994, however, a new Government came to power. Recognizing that the exchange rate was somewhat unrealistic, it attempted a 15 percent devaluation. Instead of improving the situation, however, that devaluation triggered a major foreign exchange crisis, as Mexican citizens and foreigners alike attempted to get out of pesos and peso-denominated assets and into dollars.

With foreign support and further policy measures, the markets ceased to panic and the virtual free-fall in the exchange rate and government debt stopped. To help reduce nonperforming loans in the banks' balance sheets, the government provided for the banks to transfer part of their loan portfolio to the government, and gave the banks nontransferable ten-year government bonds in exchange.

While Mexican real GDP fell at rates of 9.2, 8.0 and 7.0 percent in the last three quarters of 1995, real GDP then began increasing in the second quarter of 1996, and grew at average annual rates above 5 percent through the first quarter of $1998 .{ }^{1}$ This remarkably quick recovery in aggregate activity has not been uniform across the economy. The tradable sector has grown strongly, while after a steep fall in 1995 the non-tradable sector has subsequently recuperated only sluggishly. Mexican exports, which had grown at an average annual rate of 5 percent from

\footnotetext{
${ }^{1}$ The only exception was the first quarter of 1997 when the growth rate was "only" 4.9 percent. But that was followed by expansion of 8.6 percent in the second quarter of 1997 .
} 
1985 to 1994 and were U.S. $\$ 74$ billion in 1994, grew at an average rate of 21 percent from 1994 to 1997 , and stood at $\$ 126$ billion in $1997 .^{2}$

The asymmetric response of the tradable and non-tradable sectors is intimately linked with the severe credit crunch that Mexico has experienced since 1995. Although fresh domestic bank lending dried up in Mexico, it was still possible for export firms to obtain financing in the international capital market, or to receive credit from upstream firms. Hence, the credit crunch did not deter the tradable sector from growing at spectacular rates. On the other hand, firms in the non-tradable sector were adversely affected by the lack of credit, as these firms had no access to international financial markets. Instead, such firms have had to finance themselves with their own resources.

A phenomenon that has gone hand in hand with the credit crunch is the steady increase in the share of non-performing loans. Even after deducting the bad loans transferred to Fobaproa, the ratio of nonperforming to total loans in the balance sheet of commercial banks increased from around $10 \%$ at the end of 1994 to $16 \%$ in 1995 and subsequently to $21 \%$ in 1996 . In 1997, this ratio rose to $30 \%$, a sizable increase, indicative of a change in banking regulation that directed banks to classify the principal in addition to the unpaid interest as non-performing.

From an ex-ante perspective the partial bailout policy pursued by Mexico seemed appropriate. In principle one would expect that high GDP growth would increase firms' profits and households incomes. As a result debtors would be able to service their debts, and banks would be able to expand credit. However, with hindsight we can see why this policy stance did not solve the banking problem. First, export firms financed themselves in international capital

\footnotetext{
${ }^{2}$ This stands in sharp contrast to the Southeast Asian performance, where exports of goods and services grew at an average annual rate of 14 percent over the 1985-94 period, and 11 percent from 1994 to 1997. The countries
} 
markets. This meant that domestic banks did not tap the growing tradable sector of the economy. It also resulted in a decrease in the quality of the pool of borrowers. Second, the banks had few resources with which to confer fresh loans because they have accumulated a large share of evergreen accounts. Third, moral hazard plagued the banking system.

An important lesson from the Mexican experience is that nonperforming loans are unlikely to disappear on their own over a span of a few years, even under a high GDP growth scenario. Furthermore, the existence of nonperforming loans is an obstacle for the banking system to adequately perform its functions. This raises the question of whether an alternative strategy under which all nonperforming loans were recognized at once and the fiscal costs were all paid up-front would be preferable.

The remarkable turnaround of the Mexican economy and the evolution of the banking problem is of interest in its own right. In addition, it is of interest to policy makers in other countries where debt-servicing difficulties and foreign exchange crisis have forced adjustment measures. In this paper, therefore, we examine the causes of the crisis, the crisis itself (insofar as it is relevant to understanding the response), and the evolution of the Mexican economy since the crisis.

While Mexico's economy has evidently performed well beyond the expectations of early 1995 in the past three years, there remain problems. We shall focus both on the positive side of the reforms and on the difficulties that remain. In a final section, we assess the lessons that emerge for other countries in light of the Mexican experience. 


\section{WHAT LED TO THE CRISIS?}

That Mexico experienced a major debt crisis in 1982 is well known. After three difficult years of stagnation following a stabilization program during which there was no fundamental change in the underlying policy stance, a second crisis loomed in 1985. By this time, policy makers in the government became convinced that fundamental reforms were necessary. Instead of tightening quantitative restrictions on imports (which were already in place and covered 85 percent of imports) as had happened in earlier crises, the currency was devalued (see Table 2 for estimates of the nominal and real exchange rates for Mexico). Tariffs were reduced, and there was a general opening of the previously highly-protected manufacturing sector. Privatization was started by President de la Madrid. However, the rate of inflation rose sharply, and by 1987 had reached an annual rate of 100 percent.

Further reforms were undertaken, this time with a view to bringing down the rate of inflation, but without any intent to reverse the previous opening of the economy. There was a sharp nominal devaluation, from 1378 pesos per dollar at the end of 1986 to a 2273 pesos per dollar at the end of 1987 while at the same time, the fiscal deficit was significantly reduced from 13 percent of GDP in 1986 to 5 percent of GDP in 1989 (see Table 4). Politically, it was deemed important that the inflation rate be brought down sharply. To achieve that objective, in addition to fiscal adjustments, the authorities adopted the exchange rate as the "nominal anchor." Under this policy the range within which the exchange rate would be allowed to move was predetermined, and at a rate below the expected differential in the inflation rate between Mexico and the United States, the country with which Mexico conducted more than 70 percent of her merchandise trade. 
The theory underlying the use of a nominal anchor exchange rate policy is that, in an open economy, the domestic price of tradable goods is determined via the (nominal anchor) exchange rate, and so, when the exchange rate is adjusted more slowly than the rate of inflation, it serves as a "nominal anchor", bringing down the overall rate of inflation.

From 1987 until 1994, the authorities followed a nominal anchor exchange rate policy. The way in which this worked was as follows. Government officials met with leaders of the labor unions and the private sector, sometimes annually and sometimes semiannually, and negotiated a "pacto" which specified the rate of increase in the minimum wage, the rate of depreciation of the currency, and key public sector prices for goods such as electricity and gasoline. On the basis of these, a forecast for the inflation rate was set forth, which was essentially above the rate of currency depreciation. Since rates of depreciation were government-determined while forecasts of inflation were usually accurate or on the low side, this resulted in real appreciation of the exchange rate, as can be seen in Table 2. Starting in 1987, right after a large devaluation, the real exchange rate appreciated sharply, falling from 139 in 1987 (with an index of 1990 equaling 100) to a low of just under 79 by 1993. Simultaneously real wages in the manufacturing sector increased significantly during this period as shown in Table 5 .

As can also be seen in Table 2, the rate of price increase did indeed slow down. From a rate of inflation of over 100 percent in 1987, it fell to 23 percent by 1991, and to around 9 percent by 1993. Hence, from the viewpoint of inflation, the Mexican policy combination - a relatively balanced fiscal account combined with the nominal anchor - seemed successful.

Mexico's debt problems were greatly reduced, despite the sharp decline in the price of oil in 1986. The debt service ratio of 423 percent of exports in 1986 fell to 205 percent in 1993, 
and interest payments on outstanding foreign debt fell from 40.4 percent of export (of goods and services) earnings in 1982 to 10.9 percent in 1993. These changes were all the more remarkable in light of the devaluations of the 1980s, which raised debt servicing obligations in domestic terms. ${ }^{4}$

In addition to the fiscal-trade regime reforms, the authorities began to undertake serious reforms in the rest of the economy. There was a conscious effort to reduce the role of the public sector and to rely on private enterprise for the bulk of economic activity. The scope of reforms was enormous, encompassing privatization, removal of regulations, tax reforms, changes in landholding arrangements in rural areas, and generally greatly reducing the role of the state in economic activity. Table 7 gives a chronology of major economic events in Mexico since 1980. In many regards, Mexico's decision to enter into the North American Free Trade Agreement was a signal of the intent to open up markets and shift to reliance on the private sector for future development prospects, as well as an effort to signal and insure that reforms were irreversible.

However, there were difficulties. First of all, the Mexican rate of economic growth was relatively low, especially when the stagnation of the early 1980s and the relatively rapid rate of growth of the labor force was taken into account. As can be seen in Table 1, even by 1988 real GDP had barely surpassed its 1981 level (which implied a drop in per capita income in excess of 15 percent), while from 1987 to 1993 Mexican real GDP only grew at an average annual rate of around 3 percent. Meanwhile, during the 1980s the Mexican population and labor force grew at an average annual rates of 2.3 and 3.5 percent, respectively. Both growth rates slowed

\footnotetext{
${ }^{4}$ Data are from World Bank, World Debt Tables $1994-95$, Mexico pages.
} 
substantially after 1990, with average rates of growth from 1990 to 1995 of 1.9 percent for population and 2.8 percent for the labor force. ${ }^{5}$

This slow growth was accompanied by, and in part caused by, a relatively slow growth of exports combined with a rapid growth of imports and a deteriorating current account balance. As can be seen in Table 3, exports rose gradually from 1987 to 1994, but imports rose sharply, with the current account deficit increasing from virtual balance in 1986-88 to a deficit of around US\$30 billion in 1994. As a percentage of GDP, that was the equivalent of an increase from near zero to almost 8 percent of GDP (see Table 3). This deterioration in the current account was associated with a fall in domestic savings. As a percentage of GDP, savings fell from 22.0 percent in 1987 to around 16 percent in 1994. Investment, however, held fairly constant as a percentage of GDP.

Slow growth was partly attributable to restructuring, especially in Mexican industry, that was taking place in response to privatization, deregulation, and the removal of trade barriers, and later in response to the prospect of entry into NAFTA. However, the period during which the Mexican real rate of growth was low -- in the 3-4 percent range -- was far longer than can be explained simply by restructuring: the increasingly appreciated real exchange rate stood as a disincentive to exports and, as such, resulted in a significantly slower rate of growth of exports than would normally be expected after a switch in incentives. ${ }^{6}$

To be sure, these developments were interrelated. Real exchange rate appreciation reduced the profitability of exporting and increased the relative profitability of producing

\footnotetext{
${ }^{5}$ Data are from World Bank, World Development Report, 1997, Appendix Table 4.

${ }^{6}$ Chile also experienced very slow growth from the beginning of reforms (in 1975) until the mid 1980s. But the real growth rate in the late 1970s was over 5 percent. Interestingly, in the early 1980s the Chilean peso was allowed to appreciate by more than 30 percent in real terms (as Chile followed a nominal anchor exchange rate policy), and at the same time, the world price of copper fell sharply.
} 
nontradable goods, such as office buildings and residences. But since the real exchange rate appreciation also helped hold down the rate of inflation, it induced larger capital inflows (to take advantage of higher nominal rates of interest in Mexico) than would otherwise have occurred. The capital inflows supported the relatively appreciated real exchange rate, and therefore obscured the fact that the nontradable sector was expanding rapidly while the tradable sector was increasingly tipped toward increased imports and a large current account deficit.

There are indications that, by 1992 or 1993, the authorities were aware of the overvaluation of the peso. However, Mexican authorities stated that they had little choice but to maintain nominal anchor exchange rate policies, arguing that any larger change in the exchange rate would simply trigger offsetting nominal wage increases. ${ }^{7}$

Capital inflows were increasing and there clearly did not appear to be imminent danger. Analysts pointed out that the Mexican government's fiscal accounts were in overall primary surplus, and that the net capital inflow was destined to the private sector. Furthermore, Mexico's experience with policy reform was held up as a stellar example of how a developing country could perform. ${ }^{8}$ Even the exchange rate was defended by some as being realistic as late as the end of $1992 .{ }^{9}$ For example, Claudio Loser (an official at the IMF) and Eliot Kalter authored an International Monetary Fund Occasional Paper in September 1992, which discussed Mexican exchange rate policy, and stated that "...The authorities have been successful ... In the process the peso appreciated in real terms at a time when the balance of payments strengthened,

\footnotetext{
${ }^{7}$ See Pedro Aspe, 1993, for a description of Mexican policies and an explanation of the need for "el pacto" and similar policies. Aspe, Economic Transformation the Mexican Way, MIT Press, Cambridge. Aspe was Finance Minister for Mexico during the Salinas Presidency from 1988 to 1994.

${ }^{8}$ See, for example, Arnold C. Harberger, "A Handful of Heroes," American Economics Review Papers and Proceedings, May 1993.

${ }^{9}$ To be sure, there were some dissenting voices. See Rudicher Dombusch and Alejandro Wemer, 1994. "Mexico: Stabilization, Reform, and No Growth," Brookings Papers on Economic Activity I; and Anne Krueger and Pablo
} 
helped by a process of external liberalization and reform that the authorities pursued..." ${ }^{10}$ At the same time the OECD advocated pegging the peso to the dollar without any change in the nominal exchange rate in that same year. ${ }^{11}$ Nonetheless, the sheer size of the current account deficit and the increasing overvaluation of the peso created a significant vulnerability for Mexico.

\section{1 The Crisis}

During the course of 1994, a number of "accidents" occurred. ${ }^{12}$ There was, first of all, the beginning of the Chiapas uprising, in response to the formal commencement of NAFTA. That may have served to alert foreign investors to potential political dangers in Mexico. But equally dramatic and probably more important, there were two important political assassinations during the year, in late March when the designated candidate for President, Donaldo Colosio was gunned down, and in September the Secretary General of the PRI was assassinated. After each assassination, there was a sizable capital outflow. As a result, foreign exchange reserves dropped from 30 billion dollars in February 1994 to 17 billion in April, and to around 12 billion in early December.

It is often argued that the fall in reserves was the inevitable result of the negative shocks that Mexico experienced in 1994. This is not correct. The fall in reserves resulted from the confluence of the political shocks and the policy response. After the exchange rate hit the ceiling of the band in the aftermath of Mr. Colosio's assassination, monetary authorities decided to keep

Barahona, 1991, "The Mexican Program of Trade and Exchange Rate Reform” (in Spanish), Quantum Monterey, Mexico.

${ }^{10}$ Claudio Loser and Eliot Kalter, 1992. Mexico: The Strategy to Achieve Sustained Economic Growth, International Monetary Fund Occasional Paper 99, Washington, D.C. December P.1

${ }^{11}$ OECD, 1992. Economic Surveys. Mexico. OECD Paris.

${ }^{12}$ In addition to the factors enumerated here, U.S. interest rates were rising during 1994, which would in any event have increased the cost of debt servicing and floating new issues. 
the exchange rate virtually fixed and to expand domestic credit in order to fully sterilize the fall in reserves (see Figure 1 and Table 6). This policy was adopted in order to avoid a sharp increase in interest rates. Given the vulnerability of the banking system, it was feared that a sharp increase in interest rates would generate a deep recession.

In addition to expanding domestic credit, authorities decided to respond to the capital outflow by issuing short-term dollar denominated bonds, the so called "Tesobonos." The stock of Tesobonos increased from around 1.2 billion dollars at the end of 1993 to 29 billion dollars in December 1994. Since in early December reserves were only 12.5 billion dollars, the government had de facto become illiquid.

The administration of President Zedillo took over in December. It was apparently agreed by all that a change in the nominal exchange rate was seriously called for. However, when a 15 percent devaluation was announced on December 20 1994, it had the opposite effect from that intended. Foreigners and domestic residents alike rushed to attempt to convert pesos into dollars. Within a few days, the authorities gave up their efforts to support the currency, and permitted, or had no choice but to let it float. ${ }^{14}$

Nonetheless the currency continued to depreciate rapidly, and reserves were dropping rapidly. That, in turn, had several effects. Most important was the fact that the peso cost of debt rose both because of the appreciation of the dollar and because of a much higher interest rate. ${ }^{15}$ In addition, the value of nonperforming loans in the banking system increased rapidly,

\footnotetext{
${ }^{14}$ For an analysis of the policy response to the shocks that took place in 1994 see Jeffrey Sachs, Aaron Tornell and Andres Velasco, "The Collapse of the Mexican Peso: What Have we Learned?" Economic Policy, April 1996. For an account of the chronology of the Mexican crisis and the immediate response, see International Monetary, Fund, International Capital Markets. Developments, Prospects, and Policy Issues. Washington DC August 1995, Pp.53-79.

${ }^{15}$ The interest rate on 28-day Cetes repurchase agreements rose from 14.7 percent on December 19 to 17 percent on December 21 and then to 31 percent on December 28, and to 41 percent by January 18, 1995.. It fluctuated
} 
both because of dollar-denominated debt and because of the financial difficulties encountered by Mexican borrowers confronted with a higher price of foreign exchange. As explained by the International Monetary Fund, the peso devaluation and subsequent tightening of financial market conditions created asset quality problems in the peso-denominated and foreign currency loan books of Mexican banks. Foreign currency loans represented about a third of total loans made by Mexican banks as of December 1994, but many of these loans were extended to firms without sources of foreign currency income. As the credit expansion of 1991-94 had accelerated, some of the new loans were in any event extended to shaky ventures. With the recession and the peso depreciation, borrowers increasingly encountered debt-servicing problems.

The sharp rise in interest rates also affected the peso-loan portfolio. Most, if not all bank credits in Mexico have variable interest rates tied to the one-month Cetes rate or to interbank interest rates. When interest rates reached levels as high as 80 percent in the first quarter of 1995, payments ceased on a large proportion of loans of all types. Banks generally chose to restructure these loans, or simply to suspend interest payments, rather than be forced to recognize them as high-risk assets and write off a certain amount of their already declining capital by making provisions. Nevertheless, the deterioration in asset quality forced the riskweighted capital ratios of several Mexican banks below the 8 percent minimum, and in some cases, capital was even negative.

below that level, in a range of 31 to 38 percent until the week of February 22 when it reached 53 percent, and rose thereafter to 83 percent by March 15 . 


\section{POLICY MEASURES IN THE AFTERMATH OF THE CRISIS}

In January 1995, the Mexican government responded to the financial crisis, often called the "tequila" crisis, instituting a stabilization program and introducing still further measures on March 9. These programs were aimed at reducing the current account deficit, preventing inflation from getting out of control, and avoiding a meltdown of the banking system. In order to help stabilize financial and foreign exchange markets, international financial institutions and the governments of the United States and Canada assembled a loan guarantee package for Mexico at the end of January, amounting to U.S.\$52 billion.

As described in more detail below, the 1995 policy response was in stark contrast to the actions undertaken by the government during the 1982 debt crisis. At that time, the immediate response following the collapse of the foreign exchange market was to suspend payments on foreign debt, impose exchange controls, nationalize banks, and impose import licensing requirements. In the Tequila crisis, however, the government announced that structural reforms would not be postponed, that the liberalization of trade and capital flows was to be maintained, and that a futures market was to be created to cover exchange risk.

In this section, we describe the main elements of the 1995 policy package, which includes macroeconomic stabilization, the international rescue, the debt management strategy of the government, the main structural reforms, and the program to avoid a meltdown of the banking and financial system.

\section{III.1. The Stabilization Program}

In order to contain inflation, the government signed an agreement with the labor unions and the private sector in January 1995. Under the 1995 "Pacto", administered prices were to be increased by 10 percent (in the face of a far greater proportionate depreciation of the exchange 
rate) while minimum wages were to be raised by only 7 percent. At the same time, entrepreneurs agreed to limit price rises to adjustments induced by higher costs of imported inputs. Since inflation was projected to reach 19 percent, this agreement entailed a substantial fall in real wages. To ameliorate the effect that this would have had, a 3 percent income tax rebate was given to workers earning less than twice the (legally mandated) minimum wage.

The Pacto was further complemented with fiscal and monetary tightening. The initial budget for 1995, approved in early December 1994 immediately preceding the crisis, had projected a primary budget surplus of 2.2 percent of GDP. The revised budget increased the projected surplus to 3.4 percent of GDP. On the monetary policy front, it was announced that the exchange rate would be allowed to float. Under the new framework, the Central Bank was required by law to make price stability its single objective. Thus, there was no longer a commitment to peg the nominal exchange rate or maintain it within a band. Instead, the Central Bank committed itself to keep domestic credit creation below a ceiling of NP 12 billion. Given the macroeconomic projections, this ceiling was expected to finance an increase in the monetary base of no more than 21 percent in 1995.

However, these measures proved insufficient to stem capital outflows. As a result, 3month Cetes interest rates rose dramatically, peaking at over 80 percent in March 1995. In response, the government that month introduced a second stabilization package along with significant revisions to the official macroeconomic projection. Under this package, real GDP for the rest of 1995 was projected to decline by 2 percent instead of the small increase projected in January. The exchange rate was projected to average $6 \mathrm{NP} / \$$ while projected inflation was raised to 42 percent. Fiscal policy was further tightened by projecting a rise in the primary surplus (the government budget net of interest payments on the debt) from 3.4 percent to 4.4 
percent of GDP. Public spending was cut by nearly 10 percent, the value added tax rate was increased from 10 to 15 percent, and public-sector energy prices were again raised (gasoline by 35 percent and electricity by 20 percent). Monetary policy was also tightened by reducing the upper bound on Central Bank domestic credit creation from NP 12 billion to NP 10 billion for 1995, despite the upward revision in the anticipated inflation rate from 19 to 42 percent. Finally, to increase liquidity in the foreign exchange market, the government encouraged the establishment of a peso futures contract on the Chicago Mercantile exchange, which began trading in April of 1995.

Fluctuations in the prices of foreign exchange and other key variables were reduced significantly in the aftermath, and implementation, of the new stabilization program and the international rescue package. The exchange rate settled at around 6 NP per U.S. dollar and short term interest rates fell to 40 percent by the end of June.

In order to ameliorate the effects that the stabilization program was expected to have on the poor, several measures were taken. The most important were: an additional 12 percent rise in legal minimum wages for 1995, an expansion of direct support for agricultural and livestock activities through PROCAMPO, and an allocation of additional public funds to create 600,000 temporary jobs in particularly depressed areas.

\section{III.2. The Emergency Rescue Package}

As noted at the outset, a key ingredient of the short term measures was a financial rescue package that was assembled by multilateral organizations and the governments of the U.S. and Canada in the first two months of 1995. The package included resources of almost U.S.\$52 billion, although during 1995, only half was in fact used. The large amount was intended to be 
sufficient to convince the markets that the government had sufficient resources to honor its obligations.

The main components of the package were: 1) U.S.\$20 billion from the U.S. government in the form of short or medium-term swap facilities and long-term guarantees from the Treasury's Exchange Stabilization Fund; 2) U.S. \$17.8 billion through an IMF 18-month StandBy Arrangement of which U.S.\$7.74 billion was immediately paid and further disbursements were conditioned upon implementation of the economic adjustment program. The rest of the resources were provided by the government of Canada, the World Bank, and the Interamerican Development Bank.

Mexican authorities used these funds for three purposes. They were enabled to redeem maturing dollar-indexed Tesobonos. They were also able to refinance commercial banks' foreign currency liabilities. Finally, foreign exchange reserves were increased.

\section{III.3. Debt Management}

One of the main factors behind the crisis was the large amount of short-term dollar denominated government bonds, the "Tesobonos". Consequently, one of the primary objectives of the new administration was to reduce the stock of Tesobonos, which stood at U.S.\$29 billion at the end of December 1994. It was reduced to U.S. $\$ 8.9$ billion by July 1995 , and was entirely eliminated by February 1996. Most of the reduction reflected the use of the financial resources of the international support package to buy back the Tesobonos as they matured.

Once the crisis was over, the government was able to focus on lowering the funding costs of borrowing and lengthening the average maturity of the public debt. To this end, the government accelerated its repayment of the U.S. government loan: in August 1996, U.S.\$7 
billion was repaid. A final installment of U.S.\$3.6 billion repaid the entire loan in early 1997. Similarly, by April 1997 the Mexican government had repaid U.S.\$ 3.7 billion to the IMF.

During 1996 and 1997, the government lengthened the maturity of its debt by issuing Bondes (1-2 year Treasury bills) and Udibonos (5 year indexed bonds). As a result, the average maturity of the public debt increased from 283 days at the end of 1995 to 342 days in September 1997.

\section{III.4. Structural Reforms}

An important concern of the new administration was to make clear its signal that commitment to trade liberalization and deregulation programs started earlier would continue. The NAFTA agreement was ratified, and pronouncements were made supporting pro-market policies. Since that time, further reforms have been undertaken.

On the regulatory front, telecommunications services have been opened to competition, and several limitations on foreign ownership of financial institutions have been eased. Marketshare limits on NAFTA banks have been raised from 1.5 percent to 6 percent for individual banks, and from 6. to 25 percent in the aggregate. In addition, the limit on foreign ownership of share in banks controlled by Mexican groups was increased from 30 to 49 percent.

The privatization program has also been continued. The most important ones have been those of ports, airports, and railways. In the electricity and oil sectors, the privatization program has not advanced significantly since 1995.

Another important reform was the introduction of greater transparency in the conduct of monetary policy. Starting in March 1995, the Central Bank began publishing weekly balance sheet summaries including key variables such as the monetary base, foreign exchange reserves 
and net domestic credit. The Central Bank also laid out in advance its domestic credit and inflation targets for the coming, year.

Also important was a radical pension reform that transformed the previous pay-as-you-go system into a fully-funded system. The new system, introduced in July 1997, operates using individual pension accounts managed by private fund administrators. In addition to mandatory contributions, workers may make voluntary deposits in their accounts.

\section{III.5. Measures to Save the Banking System}

As discussed above, the crisis left commercial banks in critical condition. Because of the exchange rate depreciation, the huge earlier credit expansion which weakened the quality of bank lending, and the hike in the interest rate, a majority of debtors were unable to service their debts. Consequently, banks were unable to honor their foreign currency liabilities and found themselves with a much greater share of nonperforming loans than they had earlier had. To avoid a systemic crisis in the banking system, the government implemented a bailout program, and did so rapidly. The four components were: 1) a mechanism to provide immediate dollar liquidity to the banks; 2) absorption by the government of a portion of non-performing loans; 3 ) recapitalization of the banks; and 4) relief schemes for debtors. We describe each in turn.

Around 75 percent of Mexican banks foreign debt was short term, and the banks faced serious difficulties in rolling over these debts in the early months of the crisis. To assist them in refinancing maturing short-term foreign credit lines, the Bank of Mexico provided a special dollar credit window to Mexican banks at penalty interest rates.

To help reduce non-performing loans in the banks' balance sheets, the government permitted the banks to transfer part of their loan portfolio to the government, and gave the banks nontransferable ten-year government bonds in exchange. This program was and is 
administered by FOBAPROA, the equivalent of the Federal Deposit Insurance Corporation in the United States. The banks remain responsible for collecting interest on, and the recovery of, the loans transferred to FOBAPROA, and have an incentive to do so because of the illiquidity and lower rates of interest paid on the government bonds.

To increase the capitalization of the banks to the 8 percent minimum required level, a special trust fund (PROCAPTE) was created that lent funds to the banks in order to increase their capital. The amounts not repaid within five years would be converted to ordinary capital and then sold by the government.

The fourth component, relief schemes to reduce the burdens to borrowers, established a CPI-indexed accounting unit known as the UDI, and allowed loans to be re-denominated in UDIS. This was accomplished by permitting banks to transfer loans, up to their allocated quotas, to special trust funds which converted each loan to a long-term fixed-rate indexed loan, denominated in UDIS, bearing a real interest rate of 4 percent plus a margin to reflect the credit risk of the borrower. The government absorbed the costs and risks associated with the transformation of loan payments into UDIS.

An important issue that arose in 1995 was whether or not to replace the management teams in the banks that were going to receive government support. Since all the banks were de facto bankrupt, the government decided not to alter the governance structure of the banks. With the exception of very small banks, the government neither nationalized banks nor transferred control of the banks from the original management teams to new teams. 


\section{EVOLUTION OF THE MEXICAN ECONOMY: 1995-1997}

The liquidity crisis that Mexico suffered in early 1995 was reflected in an eighty five percent depreciation of the peso and an interest rate hike. This resulted in a sharp fall in economic activity. As Table 1 shows, during 1995, GDP fell 6\% in real terms. Surprisingly, the recession was short lived and the economy started to grow in the fourth quarter of 1995, achieving a GDP growth rate 5\% in 1996 and 7\% in 1997.

This remarkably quick recovery in aggregate activity has not been uniform across the economy. The tradable sector has grown strongly, while after a steep fall in 1995 the nontradable sector has subsequently recuperated only sluggishly. Figure 2, which depicts the evolution of sectoral GDP and exports clearly illustrates this point. During 1995, the construction and commerce sectors, with big non-tradable components, experienced sharp declines of $28 \%$ and $22 \%$, respectively. Even by the first quarter of 1998, these sectors had not attained the level of production they had before the crisis erupted. In contrast, sectors with significant tradable components, such as manufacturing and mining, did not suffer such a deep decline in 1995, and have subsequently experienced robust growth.

The last panel in Figure 2 makes clear how the spectacular increase in exports led the recovery. Exports of goods and services increased from 74 billion dollars in 1994 to 126 billion dollars in 1997. This dramatic increase in Mexican exports was achieved thanks to the real depreciation experienced by the Mexican peso during the 1995-1997 period, compared to the level it had during the period 1990-1994. We would like to note that the Mexican terms of trade did not improve during this period, and indeed the price of oil fell. From this experience we can derive the very important lesson that trade liberalization is not sufficient to insure a high rate of export growth. Avoiding an appreciation of the real exchange rate is also key. 


\section{IV.1 The Credit Crunch}

The asymmetric response of the tradable and non-tradable sectors is intimately linked with the severe credit crunch that Mexico has experienced since 1995. As we shall see, though fresh bank lending dried up in Mexico, it was still possible for export firms to obtain financing in the international capital market, or to receive credit from upstream firms. Hence, the credit crunch did not deter the tradable sector from growing at spectacular rates. On the other hand, firms in the non-tradable sector were adversely affected by the lack of credit, as these firms had no access to international financial markets. Instead, such firms have had to finance themselves with their own resources.

In short, Mexico's substantial real depreciation and the access to foreign credit enjoyed by firms in the tradable sector have been largely responsible for the tradable sector's spectacular growth. The non-tradable sector, on the other hand, suffered a credit crunch that resulted in a slow recovery. In what follows, we will document these facts.

A first indicator of the extent of the credit crunch is the steep decline in the total stock of lending from commercial banks to the private sector. Table 8 shows that total lending to the private sector fell 16\% in real terms from 1995 to 1996 and $12 \%$ in 1997 . Note, however, that these numbers do not reflect fully the decline in the availability of fresh loans. This is because the stock of loans to the private sector has two components: those still in the balance sheets of commercial banks, and those that have been transferred to the Central Bank under the bailout programs described earlier. It is clear that fresh loans can only be part of the stock of loans in the commercial banks' balance sheets. Unfortunately, these loans have fallen more drastically than the total stock loans: $38 \%$ in 1996 and 19\% in 1997, as Table 8 shows. 
The question arises as to whether this decline in lending to the private sector has affected mostly households and consumption, rather than firms and investment. Table 9 shows that this has not been the case. The reduction in the stock of loans has been distributed evenly across firms and households. During 1996 the real stock of loans to firms and households fell 16\% and 15\%, respectively. During 1997 these figures were $12 \%$ and 15\%, respectively.

The next point is that the credit crunch has affected mainly small and medium firms in the non-tradable sector, while leaving export firms and their affiliates virtually unaffected. Since the early 1990s export firms and their affiliates have been able to obtain financing in international capital markets. This is because firms that export a substantial portion of their sales are more likely to be able to provide collateral in the form of receivables denominated in dollars. To get some idea of the degree to which these firms finance themselves in international capital markets consider the 142 non-financial firms that are listed in the Mexican stock exchange. This set of firms is composed mainly of tradable sector firms: during 1997 this set of firms had an average exports-to-sales ratio of $40 \%$. The remarkable fact is that these firms had on average $53 \%$ of their liabilities denominated in foreign currency by the end of 1997. Furthermore, the subset of 20 firms with the highest shares of liabilities denominated in foreign currency ( $73 \%$ on average) were more export oriented than the rest of the firms. Their export-to-sales ratio was $64 \% .^{16}$

In what follows we will describe some reasons why the remarkable recovery in aggregate activity has not led to a credit expansion.

IV.2 Non-performing Loans

\footnotetext{
${ }^{16}$ Data are from Banco de Mexico, Informe Anual, 1997.
} 
A phenomenon that has gone hand in hand with the credit crunch that we described above is the steady increase in the share of non-performing loans. Table 10 shows that the ratio of nonperforming to total loans in the balance sheet of commercial banks increased from around $10 \%$ at the end of 1994 to $16 \%$ in 1995 and subsequently to $21 \%$ in 1996 . In 1997 , this ratio rose to $30 \%$, a sizable increase, indicative of a change in banking regulation that directed banks to classify the principal in addition to the unpaid interest as non-performing. It is important to note that the these numbers do not include the banks' loans that have been already transferred to the Central Bank in exchange for government bonds under FOBAPROA and the UDIs programs.

Table 10 characterizes the distribution of bad loans across a range of different users. In December of 1997, the most affected sector was "durable consumption goods" with a nonperforming ratio of 55\%. The corresponding ratios for housing loans and for enterprise loans were $42 \%$ and $27 \%$, respectively. Again, these numbers only refer to the non-intervened banks and exclude loans transferred to the government under FOBAPROA and the UDIs programs.

We should warn the reader that the share of nonperforming loans mentioned above does not imply that the remaining loans in the balance sheets of the non-intervened banks are by default performing loans. The reason for this is that a portion of these loans are nonperforming loans that have not been officially recognized by the banks as such. These are the so called "evergreen accounts," where the bank in question lends the debtor the principal and interest that the debtor was supposed to have repaid. Although these transfers are accounted as "loans", they are de-facto capitalized nonperforming loans.

A natural question to ask is why did the high GDP growth during 1996 and 1997 not lead to an increase in bank lending and to a reduction in the share of non-performing loans? In 
principle one would expect that high GDP growth would increase firms' profits and households incomes. As a result debtors would be able to service their debts, and banks would be able to expand credit. Here we mention some reasons why this has not been the case in Mexico.

First, there are no transparent and effective bankruptcy procedures in Mexico, making it almost impossible to take possession of a debtor's assets in case it fails to service its debt. This problem was only aggravated by the 1995 crisis. As a result, real domestic lending rates have been much higher than interest rates at which big tradable firms can obtain financing in world markets. In consequence, Mexican banks have lost "good customers" and have been left with firms that have no access to international capital markets either because they are small or because their earnings are not in dollars. The deterioration in the pool of borrowers and the associated reduction in the expected rate of return have resulted in an unwillingness of banks to offer higher interest rates in order to attract more deposits. As a result bank deposits decreased 4.1\% from 1995 to 1997, while the broad monetary aggregate (M4) increased 5.6\% during the same period as shown in Table 11. This unwillingness of the banks to attract more deposits had as a counterpart the reduction in the stock of loans to the private sector that we documented in the previous section.

A second reason why high GDP growth has not led to a reduction in the share of bad loans is that while the banks reduced their net lending they were simultaneously saddled with the previously mentioned evergreen accounts. Recall that these accounts are de facto nonperforming loans. Thus, the accrued interest must be capitalized every period. As a result, evergreen accounts grow exponentially, thereby reducing the capacity of banks to make new loans to fresh projects. Since each period a portion of the evergreen debtors goes bankrupt, and 
since net total lending has been declining, the natural result has been an increase in the share of reported non-performing loans.

A third reason why the share of bad loans has increased is the existence of severe moral hazard problems in the banking system. On the one hand, the lack of transparent and effective bankruptcy procedures combined with the fact that the crisis left many borrowers insolvent created the incentives for some debtors with the capacity to service their debts not to do so, since nonpayment would be hardly punished. On the other hand, the existence of evergreen accounts has left several banks with negative effective capital. That is, their capital became smaller than the sum of the recognized and unrecognized nonperforming loans. When banks have negative effective capital managers have incentives to undertake risky or white elephant projects which have a negative net expected value.

\section{EVOLUTION OF THE BANKING RESCUE PROGRAM}

As we have seen, the policy measures undertaken in the aftermath of the Tequila crisis brought about robust economic growth. Responsible fiscal and monetary policies combined with a real exchange rate depreciation paved the way for a remarkable expansion of the tradable sector and of Mexican exports. Some bank restructuring was undertaken and was a necessary condition for recovery. As a result the recession was short-lived and economic recovery resumed in 1996. Still, fast economic growth and the restructuring that was undertaken did not solve the banking problem in the sense that the share of non-performing loans has increased, while the credit extended from the banking system has decreased.

When the banking rescue package was designed, back in 1995, it was believed that as the economy came out of the recession, higher GDP growth rates would induce a reduction in the 
share of nonperforming loans without further policy intervention. Unfortunately, these projections did not materialize, and the exchange of bad loans for government bonds administered by FOBAPROA turned out not to be a once-and-for-all event. Indeed, several of these swaps took place again in 1996 and 1997 because the share of nonperforming loans kept on going up and the banks failed to increase their capital in order make the appropriate provisions.

Consequently, the rescue program that was meant to be temporary became an openended bailout mechanism. Ironically, according to the Mexican press, this rescue mechanism has induced the banking system to undertake unfavorable activities that have resulted in a greater amount of bad loans than had previously existed in 1995.

As time went by authorities had to increase their assessment of the fiscal costs associated with the banking rescue program. Table 12 shows how in 1995 the present value of the bailout costs were estimated at 5.5\% of GDP. This estimate had increased to 8.6\% of GDP in 1996. However, worse news was to come in early 1998 when the Executive asked Congress to recognize that the loan portfolio in FOBAPROA was de facto irrecoverable, and that it should be converted to public debt. The amount added up to approximately $16 \%$ of GDP.

As the Mexican experience has shown, nonperforming loans are unlikely to disappear on their own over a span of a few years, even under a high GDP growth scenario. Furthermore, the existence of nonperforming loans is an obstacle for the banking system to adequately perform its functions. This raises the question of whether an alternative strategy under which all nonperforming loans were recognized at once and the fiscal costs were all paid up-front would be preferable. 
In what follows we will analyze what such an alternative strategy would entail, and the possible reasons as to why such alternative was not adopted by the Mexican government. An immediate recognition of all non-performing loans is very likely to make the effective capital of most banks negative. As a result, regulators would have to require banks' shareholders to inject new capital and create provisions for bad loans. Since it is politically very costly to let a bank go bankrupt (specially if it is big), the government would have to inject the necessary capital and take over the banks that fail to inject fresh capital. During a financial crisis, like the one experienced by Mexico in 1995, it is very likely that the government would have to take over the majority of the banks, in which case the fiscal costs would be enormous. Therefore, the government will have to issue of long term bonds in order to finance this potentially enormous sum, and the interest rate on these bonds might be quite high.

While recognizing all nonperforming at once would increase the national debt substantially, the increase would occur only once if adequate policies are put in place to prevent recurrence. However, fresh lending would resume immediately because the problem of recovering bad loans would be decoupled from the business of making fresh loans to profitable projects. This separation could be implemented by transferring all nonperforming loans to a specialized agency that would either try to recover or securitize them.

The benefits of this strategy stem from the fact that freeing the banking system to provide fresh loans will induce greater economic growth and greater banks' profits, provided an adequate regulatory framework is in place. On the contrary, if the share of nonperforming loans does not decrease, banks will not be able to channel savings into new projects, specially those projects involving firms in the non-tradable sector and small firms that cannot access 
international markets. To the extent that banks are necessary in channeling savings to those firms, long-run economic growth will deteriorate.

We should stress that this strategy is not sufficient for banks to adequately perform their intermediation function. Another lesson from the Mexican experience is that simply cleaning the balance sheets of banks and privatizing them is not sufficient to insure good banking practices. It is also necessary to establish an effective regulatory framework and to put in place adequate bankruptcy procedures to ensure that creditors can take possession of the collateral in case of nonperformance. If these conditions are not satisfied, it is not advisable to incur the enormous fiscal costs associated with the cleansing of the balance sheets of the banking system. This is simply because a lending boom cycle will recur, banks will lend irresponsible to very risky or white elephant projects, and after a few years the share of nonperforming loans will increase again.

Next, we address the issue of why piecemeal bailout policies were undertaken in Mexico. As we explained earlier, in 1995 Mexico found itself in the midst of a liquidity crisis. Important sums of dollar denominated short term bonds (the Tesobonos) were due in 1995, and the government was unable to rollover these bonds. The situation was so critical that the US Treasury and the IMF had to structure a rescue package for Mexico. Understandably, meltdown of the payment system and of the economy was highly feared. Thus, the primary objective was to minimize "systemic risk."

Hence, a comprehensive one-time recognition and cleansing of bad loans was considered very dangerous in 1995. First, it was feared that forcing a recognition of all bad loans would reveal that the situation was worse than what foreign investors perceived it to be. Such a revelation would prevent Mexico from rolling over its short run liabilities. Second, 
policymakers anticipated that the government would have to take over a large segment of the banking system, as the shareholders were not expected to sufficiently increase the banks' capital. The policymakers' analysis of the government's role exposed three potentially devastating costs: (1) the government would have to increase national debt significantly at a time when it had trouble rolling over its short term liabilities; (2) nationalizing the banks could be interpreted by the market as a signal that the government was opposed to "free markets" and privatization; (3) from a political economy perspective, such a move would involve changing the coalition of powerholders that supported the regime. That is, a nationalization of the banking system would have forced the Executive to find support in the so called PRI Dinosaurs and other agents that were opposed to market oriented policies.

Furthermore, as mentioned earlier, a solution to the banking problem required a radical reform of bankruptcy procedures, so that a creditor would be able seize the assets of nonperforming debtors. In 1995, however, such a seizure of debtors assets by creditors became a very sensitive political issue. In fact, debtors had organized themselves into a powerful group, "Barzon," and the threat of a debtors revolt was very high. Politicians viewed this matter very seriously and were not inclined to reform bankruptcy procedures in the manner indicated above. However, though the above reasons may have been valid in early 1995, they ceased to be so in 1996. First, by early 1996 all Tesobonos were repaid, the economy started to recuperate, and the credentials of President Zedillo as a free market reformer were firmly established. As these three factors successfully eased the previous worries of the Mexican government, it must be asked why a definitive solution to the "non-performing loans" problem was not implemented either in 1996 or in 1997? The seemingly paradoxical answer is that Mexico had the misfortune of being lucky! As explained above, Mexican exports grew spectacularly, and the growth of the 
export sector was more than enough to compensate for the fall in services, construction and other non-tradables. This "lucky" event eliminated the immediacy of the crisis and the necessity to fix the banking problem. The authorities adopted a panglosian diagnostic: the growth of the export sector would be sufficiently strong for an adequately lengthy period such that the share of bad loans would eventually decline. Hence, policymakers concluded that the optimal policy involved the continuance of piecemeal bailout programs.

With hindsight we can see why this policy stance did not solve the banking problem. First, export firms financed themselves in international capital markets. This meant that domestic banks did not tap the growing tradable sector of the economy. It also resulted in a decrease in the quality of the pool of borrowers. Second, the banks had few resources with which to confer fresh loans because they have accumulated a large share of evergreen accounts. Third, moral hazard plagued the banking system. 


\section{LESSONS FROM THE MEXICAN EXPERIENCE}

As the review of the evolution of the Mexican economy has demonstrated, Mexico's performance to date has been impressive, although problems remain. The rapid initial policy response enabled the resumption of growth in the economy, fueled by the export response to the real exchange rate depreciation. The initial burst of inflation was rapidly damped, and prospects are for a rate of inflation in 1998 of less than 15 percent (contrasted with more than 50 percent in 1995). The longer-term problems stem from the persistence of the high ratio of nonperforming loans in the banking system that has choked off growth for firms that have no access to international capital markets.

In this section we draw lessons from the Mexican experience about how to avoid a crisis, and on the policy alternatives once the crisis has erupted. First, the real appreciation of the peso between 1988 and 1994 resulted in slower growth of exports, and more rapid growth of imports than was consistent with efficient resource allocation. And that slower growth, in turn, was a significant factor in the relatively lackluster overall rate of economic growth. When negative shocks hit in 1994, the underlying imbalance between incentives for tradables and nontradables production quickly resulted in a crisis. Letting the real exchange rate appreciate over a significant period of time is to invite a crisis.

The second lesson from the pre-crisis situation, is that, in an open economy the creation of domestic credit is virtually identical to the creation of additional liabilities denominated in foreign exchange. It is nearly impossible to provide an environment for open trade without having sufficiently relaxed regulations governing the capital account so that those wishing to move their assets from one country to another can do so readily. In this scenario, moves which were essential to establish a base for accelerated growth, such as financial deregulation and the 
opening of the economy, intensified the vulnerability of the Mexican economy to international capital flows. In this respect, the costs of having attempted to contain the capital outflow at the end of 1994 would have been steep: certainly, the open Mexican trade regime would have had to be abandoned, and tight exchange controls put in place. Even then, it is doubtful that capital outflows could have been contained, as the very act of attempting to control capital flight would have intensified peoples' desire to get out of pesos and into other currencies.

The third lesson is that in the absence of a strong regulatory framework financial deregulation might lead to a lending boom, which in turn creates vulnerabilities in the banking system. When domestic credit expands too rapidly, the quality of the banks' portfolios deteriorate. As a result even a small negative shock can drive many loans into nonperforming status, and generate banking and balance of payments crises.

Those lessons, of course, pertain to avoiding a crisis in the first place. What can the Mexican experience teach about policy alternatives once a crisis has set in? Obviously, each crisis is different, and no lessons - however appropriate for one country - can be mechanically applied to any other country without consideration of circumstances. Nonetheless, some broad general conclusions do emerge. We turn here to those lessons, noting first the policy lessons that we believe originate from the appropriateness of Mexican government responses. We then turn attention to the remaining weaknesses and conjecture as to how they might have been avoided.

We note first that one thing proven conclusively by the Mexican experience is that it is possible to recover rapidly from such a crisis. The Mexican authorities' willingness to continue economic reforms, and clear commitment to maintaining a market-based system, was of obvious importance in enabling the turnaround in economic activity. Had there been significant doubts about the sustainability of the trade or exchange rate regime, it is doubtful whether foreign 
bankers would have been willing to extend credit to Mexican exporters; that, in turn, would have meant slower growth of exports and a significantly slower recovery. Had there been significant doubts about the government's commitment to a market-based system, it is doubtful whether large Mexican firms would have been willing to undertake the liabilities associated with expanding their export capacity.

The second lesson is that there is little choice but to let the exchange rate float. Once it is floating, fluctuations in the rate diminish sharply once peoples' confidence in the authorities and in the situation is restored. In a world of capital mobility, it makes no sense to attempt to peg the exchange rate again; that simply enables the development of vulnerability for a future crisis. ${ }^{17}$

The third lesson is that recovery is not possible unless the banking system has been "fixed". If there are sizable portions of banks' portfolios that are nonperforming, the banks themselves cannot extend new loans at reasonable interest rates. Despite Mexico's impressive recovery, the data speak for themselves: the small and nontradable firms have recovered only sluggishly and are starved for credit. It is only the creditworthiness of the large and tradable firms that has enabled them to obtain financing internationally at reasonable rates.

There are some who might argue that a policy alternative could be to wait, on the grounds that, as the economy recovers the share of nonperforming loans will diminish. But Mexico's experience does not lend support to this position because nonperforming loans have increased as a proportion of the banks' portfolios despite the Mexican government's efforts. Thus, it would appear that waiting makes the problem worse as new loans are extended to

\footnotetext{
${ }^{17}$ A few countries have chosen a currency board, which is probably the only viable and desirable long-term alternative to a floating exchange rate in a country with an open trading regime. There are potential costs to a currency board, and in most circumstances, those costs probably exceed the benefits. At any event, there is nothing in the Mexican experience to shed light on the behavior of key macroeconomic variables under currency boards.
} 
cover bad old loans. Indeed, there are several reasons why the "bad loans" problem is not likely to disappear without further policy. First, when the share of bad loans is large, the interest rate at which domestic banks lend is high. Due to the higher domestic interest rate, big export firms will find it profitable to finance themselves abroad. As a result, domestic banks lose the fast growing and high quality end of the market and, instead, are left with small and non-tradable firms. Second, maintaining a large share of unrecognized nonperforming loans ("evergreen accounts"), would force banks to allocate more resources to finance existing non-performing loans. ${ }^{18}$ As a result, the share of non-performing loans would increase further despite a high GDP growth.

Hence, we conclude that a major lesson from Mexico is that the problem of cleaning up the banks' portfolios requires decisive and immediate action. Delay is likely both to prevent recovery and response to the altered exchange rate, and to lead to an even larger problem that will ultimately have to be addressed in order for satisfactory growth to resume.

A fourth, and somewhat more conjectural lesson, has to do with the existence of systemic risk. It can be cogently (but not conclusively) argued that, had the Mexican authorities failed to take action in early 1995, they might have been unable to control a cumulative spiraling contraction of credit. Had that happened, recovery would have been impossible until it was halted, and that, in turn might have required much stronger action once the spiral was underway.

A fifth lesson that derives from the Mexican experience in the early 1990s is that the problem of the banks requires not only the initial and rapid removal of the bad paper from their

\footnotetext{
${ }^{18}$ There is also the consideration, mentioned above, that when the banks are significantly undercapitalized, there are strong incentives for lenders to take extreme risks: if they win, they gain; if they lose, they would have lost anyway.
} 
portfolios and their establishment on a sound capitalized basis, but also a rapid imposition of mechanisms (both in the form of incentives and in supervisory institutions) and standards to insure that the problem does not recur. Failure to achieve adequate incentives and provisions for maintaining the quality of bank loans can, if left unchecked, result in yet another buildup of nonperforming loans.

Lastly, we would like to note that the fiscal deficit was not a significant factor in contributing to the crisis; the Mexican authorities held steady with fiscal behavior in the wake of the crisis, which was undoubtedly essential to the successful outcome Mexico had. ${ }^{19}$ But for countries that enter into a crisis with severe fiscal imbalances, it would obviously be imperative to address the sources of imbalance as a crucial initial step in addressing the crisis; Mexico offers no lessons for that because it had no problems in that dimension.

As we have seen, the lessons from Mexico are mostly positive. Recovery can come about quickly, and stability can be restored. To achieve these desirable ends requires rapid action with regard to monetary and fiscal policy, the exchange rate, and the banking system. Delays can only slow down recovery. But, in addition to the immediate challenge lies the need to insure that the problem does not happen again. That, in turn, requires rapid action with regard to prudential supervision and incentive mechanisms to assure the quality of future lending of the banking system.

\footnotetext{
${ }^{19}$ It should be noted that the Mexican authorities have reduced fiscal expenditures to maintain fiscal balance as the government's prospective revenues from oil have diminished with the decline in the oil price. This behavior has undoubtedly been important for sustaining success in reducing the inflation rate and maintaining credibility of the government's monetary, fiscal, and exchange rate policies.
} 
Table 1a: Mexican Real GDP

$\begin{array}{llr}\text { Year } & \begin{array}{l}\text { Real GDP } \\ \text { (Millions of } \\ \text { 1993 Pesos) }\end{array} & \begin{array}{c}\text { Real GDP } \\ \text { (\% change) }\end{array} \\ 1980 & 3794429.3 & \\ 1981 & 4117927.5 & ----- \\ 1982 & 4096481.0 & 8.53 \\ 1983 & 3953660.2 & -0.53 \\ 1984 & 4088512.3 & -3.49 \\ 1985 & 4177956.4 & 3.42 \\ 1986 & 4049319.0 & 2.19 \\ 1987 & 4119066.1 & -3.08 \\ 1988 & 4171924.6 & 1.73 \\ 1989 & 4343203.1 & 1.29 \\ & & 4.11 \\ 1990 & 4567997.3 & \\ 1991 & 4760527.2 & 5.18 \\ 1992 & 4929102.4 & 4.22 \\ 1993 & 5024783.9 & 3.55 \\ 1994 & 5248801.7 & 1.95 \\ 1995 & 4922432.0 & 4.46 \\ 1996 & 5176606.6 & -6.22 \\ 1997 & 5539297.9 & 5.17 \\ & & 7.01\end{array}$

Source: INEG/ web page: $h$ ttp://www.inegi.gob. $m \times /$ 
Table 1b: Mexican Real GDP

$\begin{array}{llc}\text { Year/Quarter } & \begin{array}{l}\text { Real GDP } \\ \text { (Millions of } \\ \text { 1993 Pesos) }\end{array} & \begin{array}{l}\text { Real GDP } \\ \text { (\% change) }\end{array} \\ \text { 1994/01 } & 1277838.0 & \\ 1994 / 02 & 1331435.1 & 2.3 \\ 1994 / 03 & 1267386.3 & 5.6 \\ 1994 / 04 & 1372142.3 & 4.6 \\ & & 5.2 \\ 1995 / 01 & 1272241.6 & -0.4 \\ 1995 / 02 & 1209052.7 & -9.2 \\ 1995 / 03 & 1165580.2 & -8.0 \\ 1995 / 04 & 1275557.5 & -7.0 \\ 1996 / 01 & 1273411.2 & 0.1 \\ 1996 / 02 & 1287671.8 & 6.5 \\ 1996 / 03 & 1248864.3 & 7.1 \\ 1996 / 04 & 1366659.3 & 7.1 \\ 1997 / 01 & 1335407.3 & \\ 1997 / 02 & 1398121.7 & 4.9 \\ 1997 / 03 & 1347608.0 & 8.6 \\ 1997 / 04 & 1458160.9 & 7.9 \\ 1998 / 01 & & 6.7 \\ & 1423550.9 & 6.6\end{array}$

Source: INEGI web page: $h t t p: / / w w w . i n e g i . g o b . m \times /$ 
Table 2a: Mexican Real Exchange Rate

Year MEX CPI
$1990=100 \%$ change
MEX WPI MEX WPI US WPI

$1990=100 \%$ change $1990=100$
XR

(New Peso/US\$)

$\begin{array}{lrrrrrrr}1980 & 0.67 & 26.42 & 63.10 & 0.70 & 25.00 & 77.30 & 0.0230 \\ 1981 & 0.85 & 26.87 & 69.60 & 0.90 & 28.58 & 84.30 & 0.0245 \\ 1982 & 1.36 & 60.00 & 73.90 & 1.40 & 55.56 & 86.00 & 0.0564 \\ 1983 & 2.73 & 100.74 & 76.20 & 2.90 & 107.15 & 87.10 & 0.1201 \\ 1984 & 4.52 & 65.57 & 79.50 & 4.90 & 68.97 & 89.20 & 0.1678 \\ 1985 & 7.12 & 57.53 & 82.40 & 7.60 & 55.11 & 88.70 & 0.2569 \\ 1986 & 13.26 & 86.24 & 83.90 & 14.30 & 88.16 & 86.20 & 0.6118 \\ 1987 & 30.73 & 131.75 & 87.00 & 33.60 & 134.97 & 88.40 & 1.3782 \\ 1988 & 65.80 & 114.13 & 90.50 & 69.80 & 107.74 & 92.00 & 2.2731 \\ 1989 & 78.96 & 20.00 & 94.90 & 81.10 & 16.19 & 96.60 & 2.4615 \\ 1990 & 100.00 & 26.65 & 100.00 & 100.00 & 23.31 & 100.00 & 2.8126 \\ 1991 & 122.67 & 22.67 & 104.20 & 120.50 & 20.50 & 100.20 & 3.0184 \\ 1992 & 141.69 & 15.51 & 107.40 & 136.70 & 13.45 & 100.80 & 3.0949 \\ 1993 & 155.51 & 9.76 & 110.60 & 148.80 & 8.86 & 102.30 & 3.1156 \\ 1994 & 166.34 & 6.97 & 113.40 & 158.90 & 6.79 & 103.60 & 3.3751 \\ 1995 & 224.55 & 35.00 & 116.60 & 221.10 & 39.15 & 107.30 & 6.4194 \\ 1996 & 301.70 & 34.36 & 120.00 & 301.40 & 36.32 & 109.80 & 7.5994 \\ 1997 & 364.00 & 20.65 & 122.90 & 357.20 & 18.52 & 109.80 & 7.9141\end{array}$

Source: International Financial Statistics Yearbook 1997, IMF

Note: Real Exchange Rate Index 1 is calculated as XR*(US CPI/Mex CPI)

Real Exchange Rate Index 2 is calculated as XR*(US WPIMex WPI) 


$\begin{array}{rr}\begin{array}{l}\text { Real } \\ \text { Exchange } \\ \text { Rate Index } 1\end{array} & \begin{array}{l}\text { Real } \\ \text { Exchange } \\ (1990=100)\end{array} \\ \begin{array}{r}\text { Rate Index 2 } \\ (1990=100)\end{array} \\ 76.96 & 90.08 \\ 71.28 & 81.57 \\ 108.87 & 123.05 \\ 119.15 & 128.02 \\ 104.97 & 108.52 \\ 105.68 & 106.39 \\ 137.59 & 130.86 \\ 138.66 & 128.73 \\ 111.00 & 106.39 \\ 104.97 & 104.26 \\ & \\ 100.00 & 100.00 \\ 91.14 & 89.01 \\ 83.34 & 81.21 \\ 78.73 & 76.25 \\ 81.92 & 78.37 \\ 118.44 & 110.64 \\ 107.45 & 98.23 \\ 95.04 & 86.53\end{array}$


Table 2b: Mexican Real Exchange Rate

$\begin{array}{ll}\text { Yearl } & \text { MEX CPI MEX CPI US CPI } \\ \text { Quarter } & 1990=100 \text { ( } \% \text { change } 1990=100\end{array}$

MEX WPI MEX WPI US WPI

$1990=100 \quad(\%$ change $1990=100$
XR

(New Peso/US

$\begin{array}{llllllll}1994 / 01 & 162.50 & 7.27 & 112.30 & 154.7 & 6.62 & 102.70 & 3.1677 \\ 1994 / 02 & 165.00 & 6.94 & 113.00 & 157.4 & 6.36 & 103.30 & 3.3421 \\ 1994 / 03 & 167.40 & 6.77 & 114.00 & 160.3 & 6.73 & 104.00 & 3.3943 \\ 1994 / 04 & 170.50 & 6.97 & 114.50 & 163.2 & 7.44 & 104.40 & 3.5964 \\ & & & & & & & \\ 1995 / 01 & 186.90 & 15.02 & 115.50 & 182.4 & 17.91 & 106.20 & 5.9669 \\ 1995 / 02 & 220.70 & 33.76 & 116.50 & 216.9 & 37.81 & 107.50 & 6.1618 \\ 1995 / 03 & 237.20 & 41.70 & 117.00 & 233.6 & 45.73 & 107.70 & 6.2109 \\ 1995 / 04 & 253.50 & 48.69 & 117.60 & 251.4 & 54.05 & 107.90 & 7.3381 \\ & & & & & & & \\ 1996 / 01 & 276.60 & 48.00 & 118.60 & 276.3 & 51.49 & 108.70 & 7.5275 \\ 1996 / 02 & 296.00 & 34.12 & 119.80 & 296.2 & 36.57 & 110.00 & 7.4828 \\ 1996 / 03 & 309.60 & 30.53 & 120.40 & 309.6 & 32.54 & 110.10 & 7.5606 \\ 1996 / 04 & 324.80 & 28.13 & 121.30 & 323.6 & 28.72 & 110.30 & 7.8269 \\ & & & & & & & \\ 1997 / 01 & 347.20 & 25.53 & 122.10 & 342.3 & 23.89 & 110.50 & 7.8618 \\ 1997 / 02 & 359.00 & 21.29 & 122.60 & 352.6 & 19.05 & 109.40 & 7.9186 \\ 1997 / 03 & 369.00 & 19.19 & 123.10 & 362.1 & 16.96 & 109.40 & 7.8164 \\ 1997 / 04 & 380.70 & 17.22 & 123.60 & 371.8 & 14.90 & 109.60 & 8.0595 \\ 1998 / 01 & 400.30 & 15.30 & 123.90 & 386.1 & 12.80 & 107.50 & 8.414\end{array}$

Source: International Financial Statistics Yearbook 1997, IMF Note: Real Exchange Rate Index 1 is calculated as XR*(US CPIMex CPI)

Real Exchange Rate Index 2 is calculated as $X R^{\star}(U S$ WPI/Mex WPI) 


$\begin{array}{ll}\begin{array}{l}\text { Real } \\ \text { Exchange } \\ \text { Rate Index 1 } \\ (1990=100)\end{array} & \begin{array}{l}\text { Real } \\ \text { Exchange } \\ \text { Rate Index 2 } \\ (1990=100)\end{array} \\ 77.66 & 74.83 \\ 81.21 & 78.02 \\ 82.27 & 78.37 \\ 85.82 & 81.92 \\ & \\ 130.86 & 123.41 \\ 115.61 & 108.52 \\ 108.87 & 101.78 \\ 120.93 & 111.71 \\ & \\ 114.54 & 105.32 \\ 107.45 & 98.59 \\ 104.61 & 95.40 \\ 103.91 & 94.69 \\ & \\ 98.23 & 90.08 \\ 96.10 & 87.24 \\ 92.56 & 84.05 \\ 92.91 & 84.40 \\ & 83.34 \\ 92.56 & \end{array}$


Table 3

Table 3: Mexican Foreign Trade

Goods and Services

Year

1980

1981

1982

1983

1984

1985

1986

1987

1988

1989

1990

1991

1992

1993

\section{Year/Quarter}

1994/01

1994/02

$1994 / 03$

$1994 / 04$

$1995 / 01$

1995/02

$1995 / 03$

$1995 / 04$

1996/01

1996/02

1996/03

1996/04

1997/01

1997/02

$1997 / 03$

$1997 / 04$
Exports xports/GDP

(Millions of US\$)

$\begin{array}{ll}23983.37 & 11.70 \\ 30033.88 & 11.38 \\ 29900.31 & 16.20 \\ 31724.56 & 20.32 \\ 36446.07 & 19.78 \\ 33845.36 & 17.34 \\ 28337.83 & 21.07 \\ 35431.22 & 24.02 \\ 39824.29 & 21.93 \\ 45543.45 & 20.58 \\ 52078.56 & 19.94 \\ 55077.15 & 17.59 \\ 58263.46 & 16.05 \\ 64095.20 & 15.90\end{array}$

17241.01

18362.79

18403.68

20542.61

22139.67

22964.20

23319.71

24610.76

25680.83

27213.86

27940.66

30097.07

29332.40

31240.41

31974.26

33714.77
(\%)

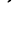

11.70

1.38

20.32

19.78

17.34

21.07

24.02

21.93

9.94

7.59

15.90

17.18

17.40

17.95

34.90

32.86

33.16

29.65

34.47

34.00

34.42

31.92

31.45

31.42

32.54

30.18
18.15
Imports ports/GD

(Millions of

(\%)

US\$)

$35250.64 \quad 17.19$

$47294.88 \quad 17.92$

$36833.12 \quad 19.96$

$27037.66 \quad 17.32$

$33624.06 \quad 18.25$

$35031.13 \quad 17.95$

$31286.64 \quad 23.26$

$33111.32 \quad 22.45$

$44456.53 \quad 24.48$

$53908.81 \quad 24.35$

$63507.90 \quad 24.31$

$72715.13 \quad 23.23$

$86088.24 \quad 23.71$

$91134.82 \quad 22.61$

$24834.36 \quad 24.74$

$26865.81 \quad 25.46$

$27360.38 \quad 26.68$

$28933.34 \quad 25.56$

$24368.10 \quad 38.41$

$23690.70 \quad 33.90$

$24844.56 \quad 35.32$

$25667.61 \quad 30.93$

$26786.61 \quad 35.95$

$28148.34 \quad 35.17$

$29962.29 \quad 36.91$

$32896.46 \quad 34.89$

$30635.03 \quad 32.85$

$33838.63 \quad 34.03$

$35913.27 \quad 36.54$

$38570.75 \quad 34.52$

Source: Banco de Mexico web page: http://www.banxico.org.mx/ 


$\begin{array}{cc}\begin{array}{c}\text { Current } \\ \text { Account (CA) }\end{array} & \text { CA/GDP } \\ \begin{array}{c}\text { (Millions of } \\ \text { US } \$ \text { ) }\end{array} & (\%) \\ & \\ -10434.10 & -5.09 \\ -16240.60 & -6.16 \\ -5890.07 & -3.20 \\ 5859.62 & 3.76 \\ 4183.35 & 2.28 \\ 799.51 & 0.41 \\ -1373.51 & -1.03 \\ 4238.96 & 2.88 \\ -2375.63 & -1.31 \\ -5821.21 & -2.63 \\ -7451.04 & -2.86 \\ -14646.72 & -4.68 \\ -24438.48 & -6.73 \\ -23399.21 & -5.81 \\ & \\ & \\ -6781.48 & -6.76 \\ -7475.85 & -7.09 \\ -7908.39 & -7.72 \\ -7496.25 & -6.63 \\ -1354.64 & -2.14 \\ 356.37 & 0.51 \\ -450.44 & -0.65 \\ -127.99 & -0.16 \\ -104.57 & -0.15 \\ 296.09 & 0.37 \\ -830.46 & -1.03 \\ -1691.34 & -1.80 \\ -150.35 & -0.17 \\ -2545.18 & -1.15 \\ -3617.89 & -2.59 \\ & -3.24\end{array}$


Table 4

Table 4: Mexican Public Sector Balances

$\begin{array}{ccc}\text { Year } & \begin{array}{c}\text { Total Fiscal Balance/GDP } \\ (\%)\end{array} & \begin{array}{c}\text { Primary Fiscal Balance/GDP } \\ (\%)\end{array} \\ 1984 & -6.11 & 5.73 \\ 1985 & -6.71 & 4.38 \\ 1986 & -12.97 & 3.31 \\ 1987 & -13.45 & 5.43 \\ 1988 & -8.72 & 7.50 \\ 1989 & -4.84 & 7.49 \\ 1990 & -2.25 & 6.89 \\ 1991 & -0.37 & 4.74 \\ 1992 & 1.43 & 5.07 \\ 1993 & 0.69 & 3.34 \\ 1994 & -0.32 & 2.00 \\ 1995 & -0.18 & 4.44 \\ 1996 & -0.13 & 4.28 \\ 1997 & -0.68 & 3.39\end{array}$

Source: Banco de Mexico website:

URL: http://Www. banxico.org.mx/public_html/inveco/infecon/ing/isfinpub.htm/ 
Table 5

Table 5: Mexican Real Manufacturing Wage Index

$\begin{array}{cr}\text { Year } & \begin{array}{r}\text { Real Manufact } \\ (\mathbf{1 9 8 5}=\mathbf{1 0 0})\end{array} \\ & 103.58 \\ 1984 & 100.00 \\ 1985 & 95.09 \\ 1986 & 91.65 \\ 1987 & 96.66 \\ 1988 & 104.59 \\ 1989 & 106.82 \\ 1990 & 117.17 \\ 1991 & 131.34 \\ 1992 & 140.31 \\ 1993 & 144.12 \\ 1994 & 112.89 \\ 1995 & 105.30 \\ 1996 & 107.26 \\ 1997 & \end{array}$

Source: Banco de Mexico webpage. URL: http://www.banxico.org.mx/ Note: Figures are end of year data. 
Table 6

Table 6: Mexican Monetary Base

(Billions of Pesos)

onth/Yea Monetary ternation Net Domestic Base Reserves Credit

$\begin{array}{rrrr}\text { Jan-93 } & 37.68 & 64.38 & -26.70 \\ \text { Feb-93 } & 36.19 & 66.30 & -30.11 \\ \text { Mar-93 } & 34.68 & 64.80 & -30.12 \\ \text { Apr-93 } & 35.23 & 74.23 & -39.00 \\ \text { May-93 } & 36.11 & 72.64 & -36.54 \\ \text { Jun-93 } & 36.06 & 69.52 & -33.47 \\ \text { Jul-93 } & 36.81 & 70.24 & -33.44 \\ \text { Aug-93 } & 35.19 & 70.38 & -35.20 \\ \text { Sep-93 } & 35.13 & 71.29 & -36.16 \\ \text { Oct-93 } & 37.15 & 71.76 & -34.62 \\ \text { Nov-93 } & 38.24 & 58.18 & -19.94 \\ \text { Dec-93 } & 47.20 & 76.22 & -29.02 \\ & & & \\ \text { Jan-94 } & 42.52 & 81.62 & -39.10 \\ \text { Feb-94 } & 41.90 & 93.52 & -51.62 \\ \text { Mar-94 } & 44.86 & 82.82 & -37.96 \\ \text { Apr-94 } & 41.90 & 56.52 & -14.62 \\ \text { May-94 } & 42.59 & 56.82 & -14.24 \\ \text { Jun-94 } & 43.39 & 54.27 & -10.89 \\ \text { Jul-94 } & 45.03 & 54.99 & -9.96 \\ \text { Aug-94 } & 44.24 & 55.50 & -11.26 \\ \text { Sep-94 } & 43.81 & 54.94 & -11.14 \\ \text { Oct-94 } & 44.76 & 59.15 & -14.39 \\ \text { Nov-94 } & 49.17 & 43.03 & 6.15 \\ \text { Dec-94 } & 56.94 & 32.74 & 24.20 \\ & & & \\ \text { Jan-95 } & 51.20 & 19.84 & 31.37 \\ \text { Feb-95 } & 49.80 & 52.41 & -2.62 \\ \text { Mar-95 } & 48.81 & 46.70 & 2.11 \\ \text { Apr-95 } & 47.56 & 50.36 & -2.81 \\ \text { May-95 } & 46.21 & 64.48 & -18.28 \\ \text { Jun-95 } & 47.03 & 63.61 & -16.59 \\ \text { Jul-95 } & 47.95 & 84.43 & -36.48 \\ \text { Aug-95 } & 47.81 & 95.13 & -47.33 \\ \text { Sep-95 } & 47.23 & 94.36 & -47.13 \\ \text { Oct-95 } & 48.48 & 96.80 & -48.32 \\ \text { Nov-95 } & 53.64 & 104.02 & -50.39 \\ \text { Dec-95 } & 66.81 & 120.31 & -53.50\end{array}$

Month/Yea Monetary ternation Net Dome Base Reserves Credit

\begin{tabular}{rrrr} 
Jan-96 & 57.94 & 114.91 & -56.97 \\
Feb-96 & 57.83 & 120.40 & -62.58 \\
Mar-96 & 59.50 & 116.77 & -57.27 \\
Apr-96 & 57.18 & 116.48 & -59.31 \\
May-96 & 60.52 & 118.40 & -57.88 \\
Jun-96 & 61.60 & 116.78 & -55.18 \\
Jul-96 & 61.49 & 123.43 & -61.95 \\
Aug-96 & 60.99 & 117.11 & -56.13 \\
Sep-96 & 61.64 & 117.66 & -56.02 \\
Oct-96 & 64.18 & 129.53 & -65.35 \\
Nov-96 & 69.36 & 128.79 & -59.44 \\
Dec-96 & 84.00 & 137.81 & -53.82 \\
& & & \\
Jan-97 & 76.73 & 148.31 & -71.58 \\
Feb-97 & 75.97 & 161.09 & -85.13 \\
Mar-97 & 79.55 & 158.64 & -79.09 \\
Apr-97 & 77.96 & 170.94 & -92.98 \\
May-97 & 80.69 & 176.25 & -95.56 \\
Jun-97 & 80.34 & 172.77 & -92.43 \\
Jul-97 & 82.75 & 175.98 & -93.23 \\
Aug-97 & 82.45 & 181.29 & -98.85 \\
Sep-97 & 80.94 & 189.94 & -109.00 \\
Oct-97 & 84.79 & 216.16 & -131.38 \\
Nov-97 & 91.07 & 209.24 & -118.17 \\
Dec-97 & 108.90 & 225.94 & -117.04 \\
& & & \\
Jan-98 & 99.10 & 242.36 & -143.27 \\
Feb-98 & 97.96 & 243.81 & -145.85 \\
Mar-98 & 95.63 & 250.50 & -154.87 \\
Apr-98 & 98.69 & 258.94 & -160.26 \\
May-98 & 101.38 & 266.28 & -164.90 \\
& & & \\
\hline
\end{tabular}

Source: Banco de Mexico webpage:

http://www.banxico.org.mx/public_html/inveco/infecon/ing/ismonyfi.html\#Base monetaria Por sus fuent 


\section{Major Economic Events}

1982

Debt Crisis

Nationalization of banks

1985

- Trade liberalization and accession to the GATT

1987

- Inflation Rate Reaches $100 \%$

- Nominal anchor exchange rate policy is implemented

- Initiation of privatization program

1991

- Privatization of Banks and financial liberalization

1994

January - NAFTA comes into force

- Chiapas uprising

March - Assassination of presidential candidate Colosio

April - Mexico is formally excepted into OECD

August $\quad-$ Mr. Zedillo is elected President

September - The Secretary General of the PRI, Mr. Ruiz Massieu is assassinated

December - Mr. Zedillo is sworn in as new President

$-15 \%$ devaluation leads to a financial crisis 
Table 8

I. Loans to the Private Sector

Porfolio of Commercial Banks

constant 1990 prices

billions of pesos

\begin{tabular}{rrrrr}
1995 & 1996 & 1997 & $\begin{array}{r}\text { \%change } \\
96 / 95\end{array}$ & $\begin{array}{r}\% \text { change } \\
97 / 96\end{array}$ \\
\hline 340.3 & 286.1 & 252.2 & $-15.93 \%$ & $-11.85 \%$ \\
275.5 & 169.3 & 137.4 & $-38.55 \%$ & $-18.84 \%$ \\
64.8 & 116.7 & 114.8 & $80.09 \%$ & $-1.63 \%$
\end{tabular}

- Loans in Banks' Balance Sheets

- Loans Transferred to the Government

II. Government securities

9.9

4.8

9.4

$-51.52 \%$

$95.83 \%$

III. Loans to local governments

$10.8 \quad 10.6$

10.1

$-1.85 \%$

$-4.72 \%$

Source: Informes Anuales del Banco de Mexico, 1995 - 1997. 


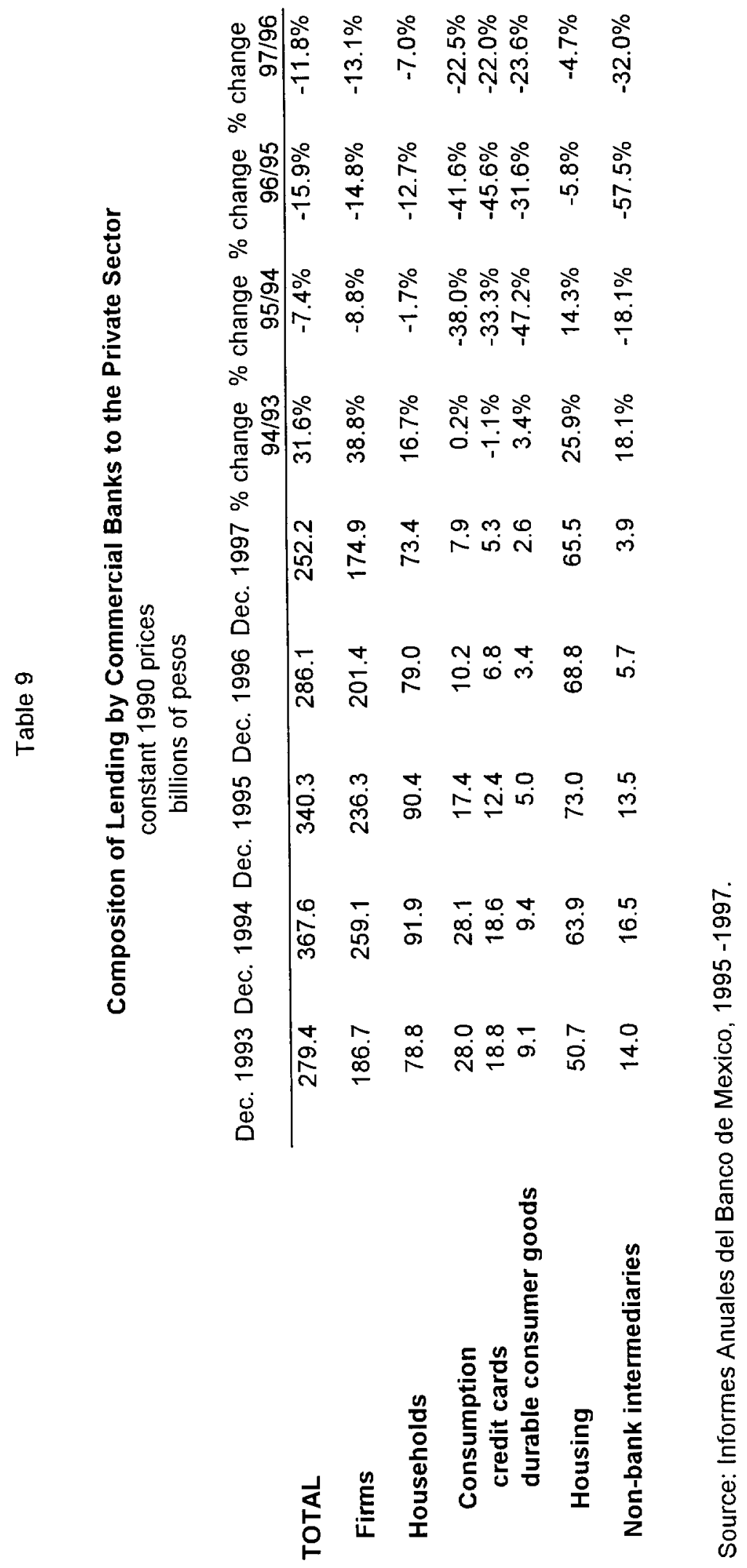


Table 10

Ratio of Nonperforming Loans to Total Loans

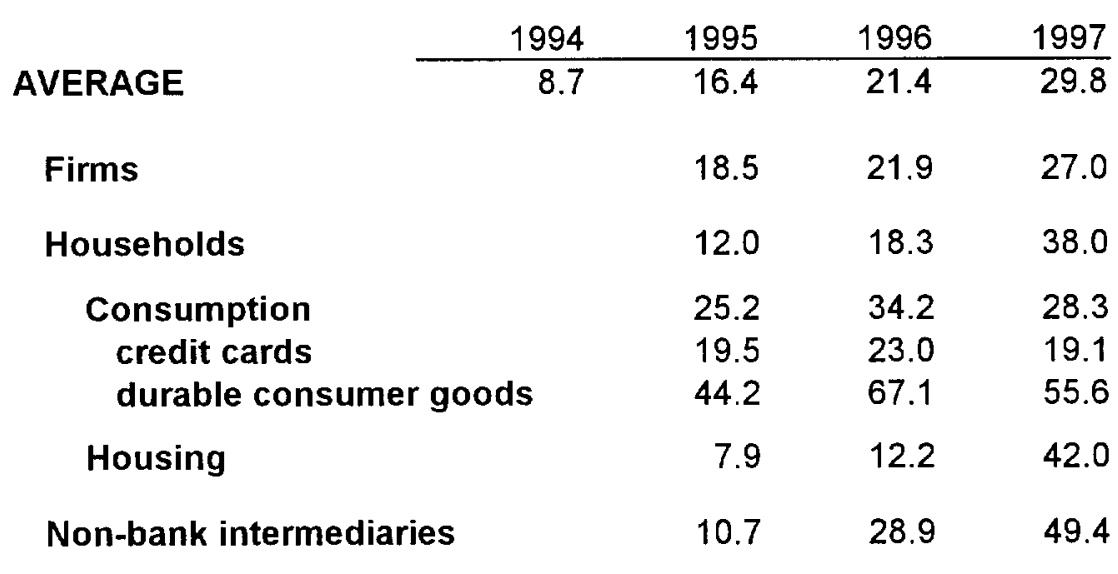

Source: Informes Anuales del Banco de Mexico, 1995 -1997. 


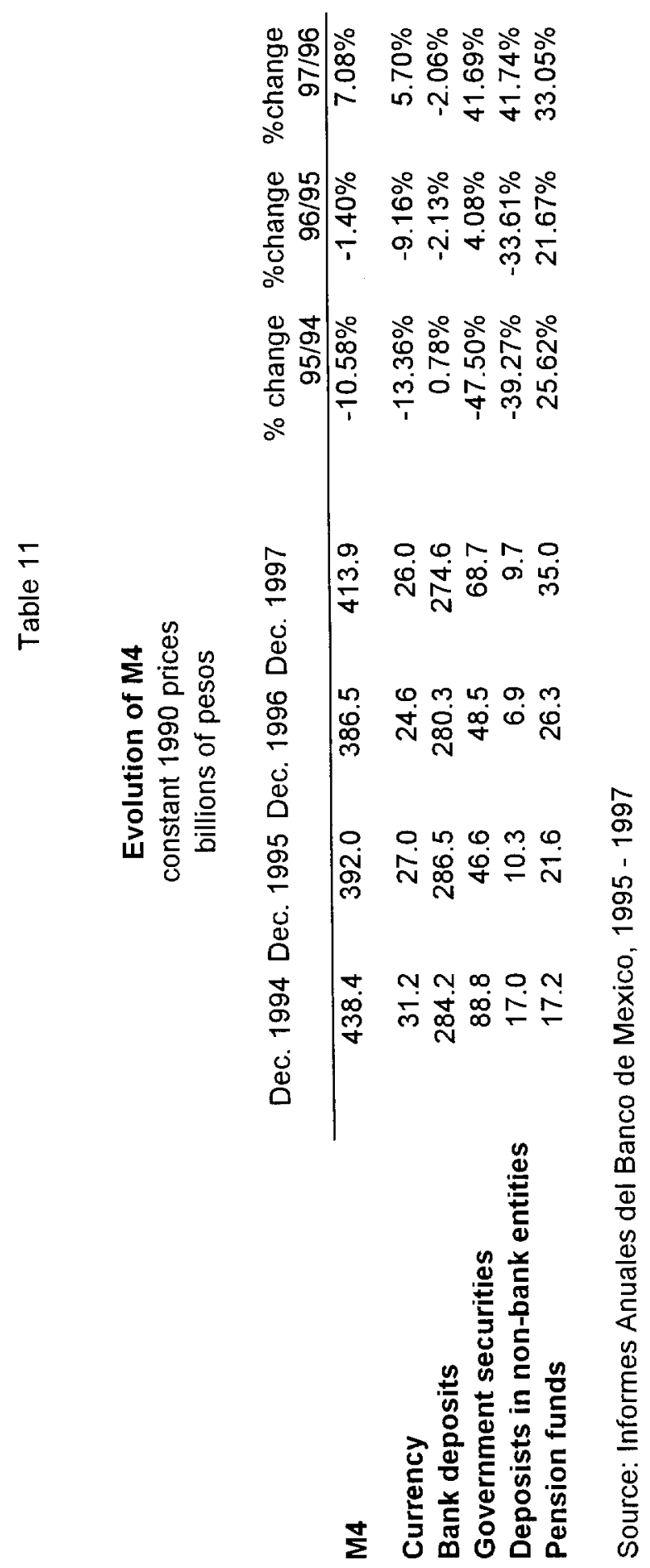




\section{Estimated Cost of the Banking Rescue Package*}

(as a share of GDP)

$\begin{array}{rr} & \% \text { of GDP } \\ 1995 & 5.5 \\ 1996 & 8.4 \\ 1997 & \text { NA } \\ 1998 & 16.2\end{array}$

* This is the ratio of the estimated present value of the cost at the end of a given year divided by the GDP of that year.

Note:

For 1995, Informe Anual del Banco de Mexico, Table 25.

For 1996, Informe Anual del Banco de Mexico, Table 40.

In 1997, the Informe Anual del Banco de Mexico did not publish this figure. The figure for 1998 is the ratio of the amount requested by the Executive to Congress in early 1998: $\$ 580,000$ million pesos to 1998 projected GDP (Source: Proceso, May 24, 1998). 


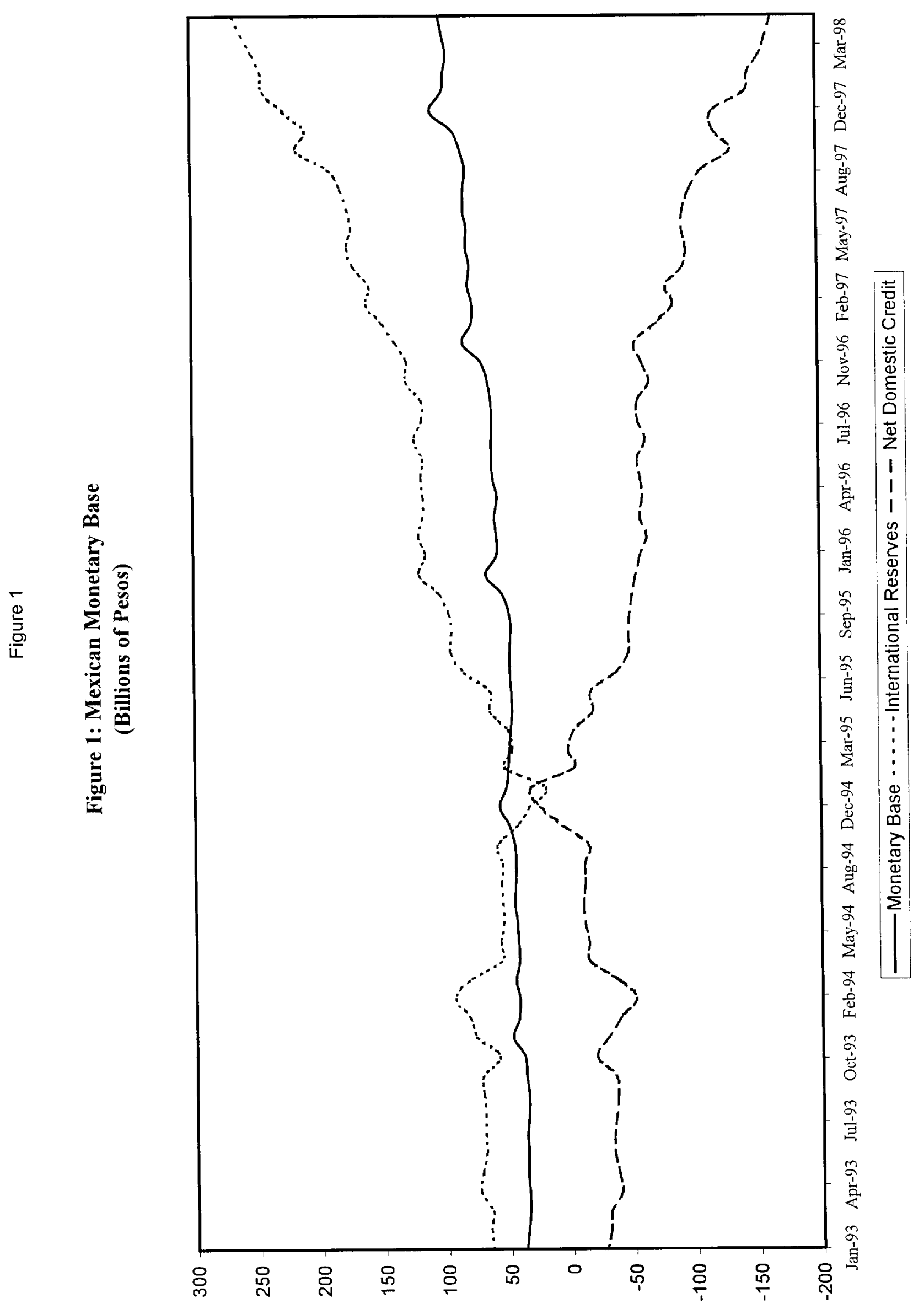




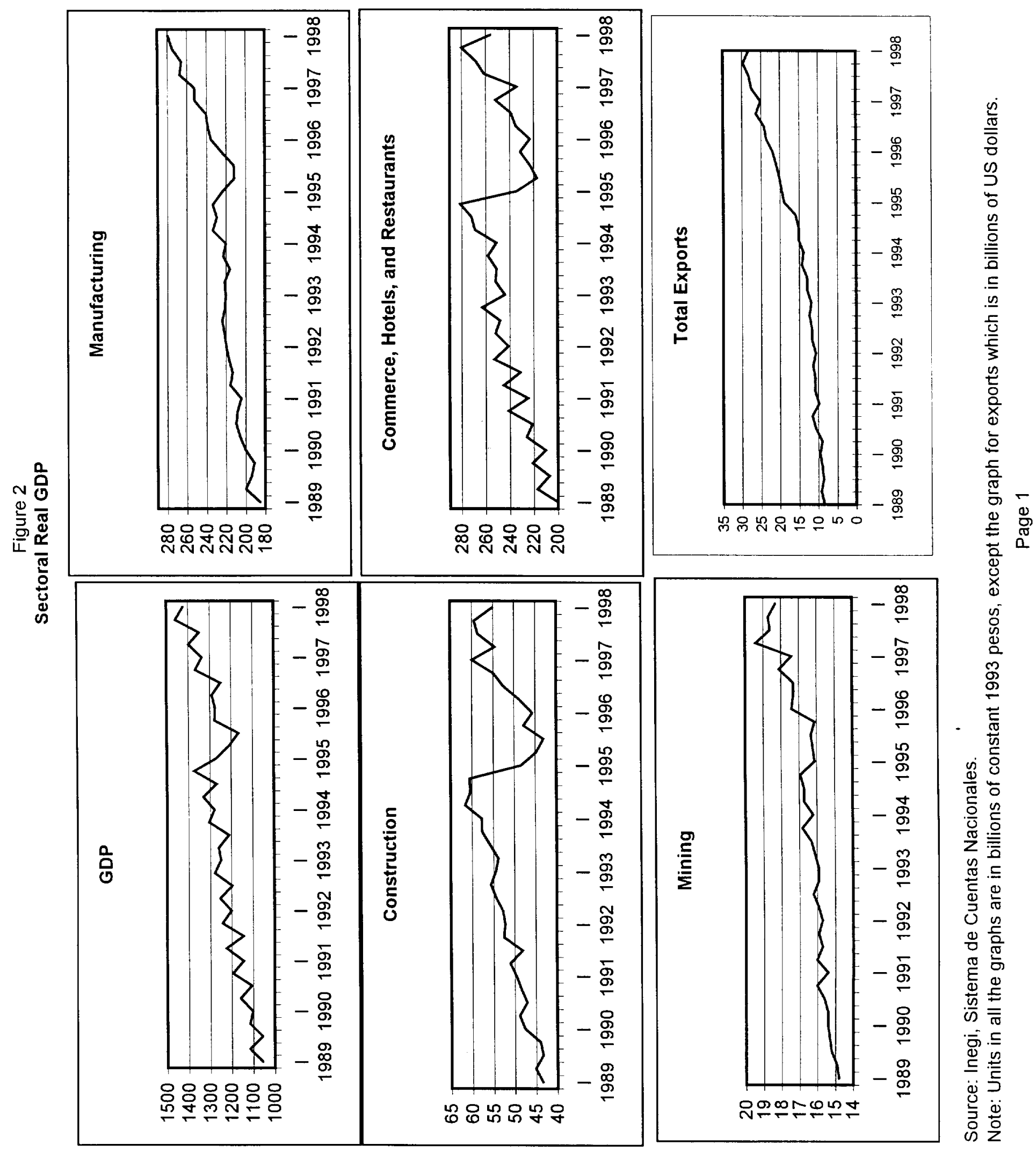

